\title{
CZECH GOVERNMENT COUNCIL ON ROMANI MINORITY AFFAIRS WORKING GROUP ON EDUCATION FOCUSES ON PREVENTING EXCLUSION IN EDUCATION
}

\author{
Gwendolyn Albert
}

The issue of exclusion in education, whether on the basis of disability, ethnicity or social status, is one that has long exercised policy designers in the Czech Republic. While access to education is declared to be a public good to which all should have equal access, at the level of practice it remains a fact that the Czech school system displays a high degree of segregation on an ethnic basis.

The Council on Romani Minority Affairs, which advises the Government on issues affecting the Romani minority, has been convening a Working Group on Education for several years now to advise the council on what they should recommend to the Government in this area. The current chair of the Working Group is Assoc. Prof. Dr. Martin Kaleja, Ph.D., Head of the Research Centre for Social Inclusion at the Faculty of Public Policies, Silesian University in Opava.

While at present none of the documentation of the meetings of this group is available through the official website of the Council, it is one of the Working Groups that has met the most consistently over the years with a rather stable constellation of experts from academia, civil society, and various state bodies. With respect to issues of social pathology and its prevention, the Working Group has focused inter alia on bullying and on how educators can be prepared for the challenge of ethnic diversity in the classroom specifically with respect to Romani children. Monitoring the impact of recently introduced changes to the financing of measures to address children's special needs ("inclusion") on Romani children, as well as the introduction of a compulsory year of preschool, has also been on the Working Group's agenda.

One of the biggest challenges to greater Romani community involvement in the everyday life of schools throughout the Czech Republic is the fact that intergenerationally, low levels of educational attainment have been the norm for the country's largest minority. As a result, the number of educationalists who are themselves Romani community members able to provide insight into crucial issues impacting Romani participation in education (such as the language of instruction differing from a child's home language) is very small, and the impact of such professionals on how the schools themselves function has been minimal to date. Romani community members who might be interested in working in the schools, whether as educators or paraprofessionals, tend not to be among those members of the workforce with the strongest qualifications for either managing schools or teaching in them. As a result, even well-intentioned policy proposals regarding early childhood education and support for the 
Romanes language tend to fail to involve the very people who potentially have the most to contribute to them and to gain from them - Romani parents - because strict conditions about educational attainment tend to be established for those meant to implement the policies. Over the years, some Working Group members have presented the opinion to the Council that the allocation of resources to the issue of preventing ethnic and racist bullying in particular in the schools has been too low. Prevention of such behavior in the schools is crucial to the creation of an environment where all feel safe and able to learn. Anti-bias education is a closely related area that has also been discussed by the Working Group. The various modalities employed to reach the education profession with such content - one-off conferences, seminars, workshops, etc. - are probably among the least impactful in terms of their potential to change behavior, but as starting points for discussion in the field they have probably served their purpose. One past member of the Working Group on Education advising the Council was also involved for a time with a Working Group on Racial Bullying at the National Education Institute.

After a Romani schoolgirl attempted suicide because of racist bullying and her story was reported by the media in 2018, the Working Group asked experts on combating this phenomenon to brief them on their experiences of attempting to impact how schools approach this issue and on what needs to be done further to prevent bullying. Compared to other issues related to the implementation of the recent legislative changes designed to bring resources for special needs into mainstream educational settings, this particular social pathology remains relatively undiscussed by the public.

Recently the Working Group has decided to refine its own procedures in order to hopefully improve its own impact on the advice it gives the Council and thereby on the expertise the Council is able to provide to the Government. Given the completely voluntary nature of membership in the Working Group and the relative lack of resources and staff at the Office of the Government who are tasked with handling the extremely extensive agenda of Romani affairs, this is a challenging endeavor. It is clear from the process of providing commentary on the current development of the Government's strategic documents on the inclusion of Romani people that one of the basic struggles includes making sure the experts and those they are advising are working with the same concepts when approaching what needs to be prevented in school environments and what needs to be promoted there so that access to a quality education will expand for all.

Those interested in learning more or in providing expertise on any of these issue should feel free to contact the Office of the Council on Romani Minority Affairs at the Office of the Government of the Czech Republic (https://www.vlada.cz/en/ppov/zalezitosti-romskekomunity/the-council-for-roma-community-affairs--50634/).

\section{Author}

Gwendolyn Albert, B. A.

Faculty of Public Policies in Opava, Silesian University in Opava

Research Centre for Social Inclusion

Bezručovo nám. 885/14, 74601 Opava, Czech Republic

gwendolyn.albert@gmail.com 